\title{
Apigenin, an Anticancer Isolated from Macaranga gigantifolia Leaves
}

\author{
Sofa Fajriah*, Megawati, Akhmad Darmawan
}

Research Center for Chemistry, Indonesian Institute of Sciences (LIPI), Serpong, Indonesia

\section{ABSTRACT}

Apigenin, a flavonoid compound has been isolated from the ethyl acetate fraction of methanol extract of Macaranga gigantifolia leaves. Isolation and purification of apigenin conducted using column and centrifugal chromatography and chemical structure characterized based on spectroscopic data. In vitro anticancer activity test against murine leukimia P-388 cell line showed potential activity as anticancer with $\mathrm{IC}_{50} 14.13 \mu \mathrm{g} / \mathrm{mL}$.

Keywords: anticancer, apigenin, flavones, Macaranga gigantifolia, murine leukemia P-388 cell line

\section{INTRODUCTION}

Macaranga gigantifolia Merr. (Euphorbiaceae), locally known as mahang-mahangan, is one of the Macaranga genus from total of 280 over than 50 species worldwide [1]. Macaranga species has long been used traditional medicine system such as $M$. gigantea and $M$. triloba used to treat fungal infections and leaf decoction, stomachaches [2]. Otherwise, Macaranga hypoleuca can be used as febrifuge, expectorant and antispasmodic and also has potential as an antioxidant, anti-bacterial [2], and anti-diabetic [3] There are only two compounds (scopoletin and macarangin) have been isolated from $M$. gigantifolia so far [4-5]. A phytochemical review indicates the genus Macaranga to be a rich source of flavonoids [6]. This paper purpose is to describe the isolation and structure elucidation of apigenin compound from ethyl acetate fraction of $M$. gigantifolia leaves, and its cytotoxic activitiy against Murine leukemia P-388 cell lines.

\section{MATERIALS AND METHODS}

\section{General}

$1 \mathrm{H}$ and 13C-NMR spectra were recorded with a JEOL JNM-ECA 500 spectrometer instrument. LC-MS was measured with Mariner Biospectrometry-Finnigan instrument. Column chromatography method carried out with silica gel (200-300 mesh, Kieselgel 60, Merck) for isolation and silica gel 60 F254 (Merck) for TLC

\section{${ }^{*}$ Corresponding author:}

Sofi Fajriah

Research Center for Chemistry, Indonesian Institute of Sciences

(LIPI), Serpong 15314, Indonesia

E-mail: sofafajriah@gmail.com with $10 \% \mathrm{H}_{2} \mathrm{SO}_{4}$ in ethanol as compound detection reagent.

\section{Plant material}

Macaranga gigantifolia leaves collected from Mekongga Forest, Kolaka District, Southeast Sulawesi, Indonesia in March 2012, and determined at Herbarium Bogoriense, Research Center for Biology, Indonesian Institute of Sciences, Bogor, Indonesia.

\section{Extraction and isolation}

About 80 grams $\mathrm{MeOH}$ extract was partitioned with $\mathrm{n}$-hexane and ethyl acetate (EtOAc), successively. The EtOAc fraction (17.4 g) subjected to silica gel chromatography column and eluted successively with n-hexane : EtOAc as mobile phase. 14 fractions (F1-F5) obtained and characterized with TLC. The compound spots detected using UV-Vis lamp and sprayed with $10 \% \mathrm{H} 2 \mathrm{SO} 4$ in ethanol. Compound A obtained from purification of fraction 12 (F12) using chromatotron (centrifugal chromatography) with n-hexane : EtOAc as mobile phase.

\section{Cytotoxic activity}

Cytotoxic activities assay conducted using MTT assay method [7-9]. Approximately $3 \times 104$ of murine leukemia P-388 cells were plated in 96-well culture dishes. Incubated at $37^{\circ} \mathrm{C}$ for $24 \mathrm{~h}$. Various concentration of sample in DMSO were added after incubation. Six desirable sample concentrations were prepared using PBS (phosphoric buffer solution, $\mathrm{pH}=7.30-7.65$ ), except control. After $48 \mathrm{~h}$ incubation, assay stopped by [3-(4,5-dimethylthiazol-2-yl)-2,5-diphenyl tetrazolium 
bromide], incubation continue for next $4 \mathrm{~h}$ before the addition of MTT-stop solution containing sodium dodecyl sulphate (SDS). The incubation continued for next $24 \mathrm{~h}$. Optical density measured with microplate reader at $550 \mathrm{~nm}$. IC50 obtained from the plotted graph between percentage live cells compared to control against various concentration of the sample tested $(\mu \mathrm{M})$.

\section{RESULTS AND DISCUSSION}

Dried M. gigantifolia leaves extracted with methanol, further partitioned successively with n-hexane and EtOAc. EtOAc fraction was chromatoraphed over silica gel column chromatography, eluted with a gradient solvent system of $\mathrm{n}$-hexane : EtOAc to obtained 14 fractions (F1-F14). Compound A obtained from further purification of fraction 12 (F12) using chromatotron (centrifugal chromatography) with nhexane : EtOAc as mobile phase.

Compound A: yellow powder, NMR (JEOL JNMECA 500) $\delta_{\mathrm{H}}(500 \mathrm{MHz}$, in DMSO-d6): 6.75 (s, $1 \mathrm{H}$, H-3), 6.15 (d, 1H, J= 1,95 Hz, H-5), 6.44 (d, 1H, J= $1,95 \mathrm{~Hz}, \mathrm{H}-8), 7.91$ (d, 2H, J= 9,05 Hz, H-2'/H-6'), 6.90 (d, 2H, J= 9,05 Hz, H-3'/H-5'), 12.94 (-OH). 13CNMR (DMSO, $125 \mathrm{MHz}) \delta 163.71$ (C-2), 102.81 (C3), 181.73 (C-4), 161.25 (C-5), 98.96 (C-6), 164.57 (C7), 94.06 (C-8), 157.37 (C-9), 103.56 (C-10), 121.17 (C-1'), 128.51 (C-2'/C-6'), 116.01 (C-3'/C-5'), 161.46 (C-4'). ESI-MS (m/z) $271.2195[\mathrm{M}+\mathrm{H}]$.

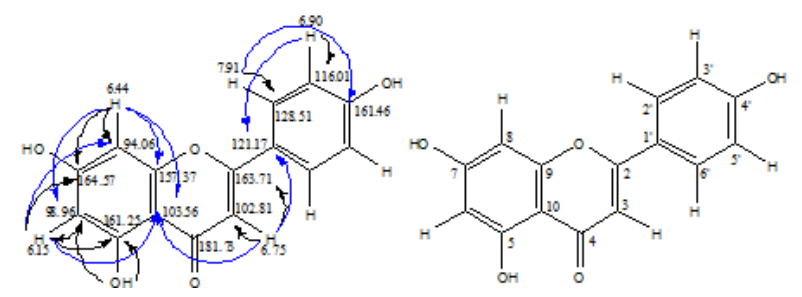

Figure 1. HMQC- and HMBC-NMR correlation of compound $A$ and chemical structure of Apigenin

The $1 \mathrm{H}-\mathrm{NMR}$ spectrum of compound A (Table 1 ), showed six aromatic protons at $\delta_{\mathrm{H}} 7.91(2 \mathrm{H}, \mathrm{d}, \mathrm{J}=9.05$ $\mathrm{Hz})$ and $6.90(2 \mathrm{H}, \mathrm{d}, \mathrm{J}=9.05 \mathrm{~Hz})$ indicated the presence of AA'XX' ring system in $\mathrm{B}$ ring. In addition, two doublet signals at $\delta_{\mathrm{H}} 6.15(1 \mathrm{H}, \mathrm{d}, \mathrm{J}=1,95 \mathrm{~Hz})$ and 6.44 $(1 \mathrm{H}, \mathrm{d}, \mathrm{J}=1,95 \mathrm{~Hz})$ showed the meta position correlation each other. This is mean that two proton signals are in the same ring system (ring A). The 13C NMR spectrum of compound A showed 15 carbon resonances (Table 1) including a downfield carbonyl signal at $\delta \mathrm{c} 81.73 \mathrm{ppm}(\mathrm{C}-4)$. Five oxyaryl carbons can be observed at $157.37 ; 161.25 ; 161.46 ; 163.71$ and 164.57, two quaternary $\mathrm{sp}^{2}$ carbons at $\delta_{\mathrm{C}} 103.56,121.17$, and seven methine $\mathrm{sp}^{2}$ carbons at $\delta_{\mathrm{C}} 94.06,98.96,128.51$ (2C), $116.01(2 \mathrm{C})$.

The HMQC $\left({ }^{1} J_{(\mathrm{C}-\mathrm{H})}\right)$ and HMBC $\left({ }^{2} J_{(\mathrm{C}-\mathrm{H})}\right.$ or $\left.{ }^{3} J_{(\mathrm{C}-\mathrm{H})}\right)$ correlations of compound A illustrated in Figure 1. The HMBC correlation between $\delta_{\mathrm{H}} 6.15$ with $\delta_{\mathrm{C}} 161.25$, 164.57, 103.56 and 94.06 together with correlations

Table 1. 1H- and 13C-NMR data of compound A and Apigenin

\begin{tabular}{|c|c|c|c|c|}
\hline \multirow{2}{*}{ No. } & \multicolumn{2}{|c|}{ Reference (Nawal \& Atta, 2013) } & \multicolumn{2}{|l|}{ Compound $\mathbf{A}$} \\
\hline & $\delta_{\mathrm{H}}($ mult., $J \mathrm{~Hz})$ & $\delta_{\mathrm{C}}$ & $\delta_{\mathrm{H}}($ mult., $J \mathrm{~Hz})$ & $\delta_{\mathrm{C}}$ \\
\hline 1 & & - & & - \\
\hline 2 & & 164.19 & & 163.71 \\
\hline 3 & $6.47(\mathrm{~s}, 1 \mathrm{H})$ & 103.30 & $6.75(\mathrm{~s}, 1 \mathrm{H})$ & 102.81 \\
\hline 4 & & 182.21 & & 181.73 \\
\hline 5 & & 161.95 & & 161.25 \\
\hline 6 & $6.21(\mathrm{~d}, 1 \mathrm{H}, \mathrm{J}=2.5 \mathrm{~Hz})$ & 99.89 & $6.15(\mathrm{~d}, 1 \mathrm{H}, \mathrm{J}=1,95 \mathrm{~Hz})$ & 98.96 \\
\hline 7 & & 163.31 & & 164.57 \\
\hline 8 & $6.77(\mathrm{~d}, 1 \mathrm{H}, \mathrm{J}=2.5 \mathrm{~Hz})$ & 94.55 & $6.44(\mathrm{~d}, 1 \mathrm{H}, \mathrm{J}=1,95 \mathrm{~Hz})$ & 94.06 \\
\hline 9 & & 157.86 & & 157.37 \\
\hline 10 & & 105.83 & & 103.56 \\
\hline $1^{\prime}$ & & 121.63 & & 121.17 \\
\hline $2^{\prime} \& 6$ & $7.93(\mathrm{~d}, 2 \mathrm{H}, \mathrm{J}=8 \mathrm{~Hz})$ & 128.98 & $7.91(\mathrm{~d}, 2 \mathrm{H}, \mathrm{J}=9,05 \mathrm{~Hz})$ & 128.51 \\
\hline $3^{\prime} \& 5$ & $6.92(\mathrm{~d}, 2 \mathrm{H}, \mathrm{J}=8 \mathrm{~Hz})$ & 116.51 & $6,90(\mathrm{~d}, 2 \mathrm{H}, \mathrm{J}=9,05 \mathrm{~Hz})$ & 116.01 \\
\hline 4 & & 161.79 & & 161.46 \\
\hline
\end{tabular}


showed by proton $\delta_{\mathrm{H}} 6.44$ with carbons at $\delta_{\mathrm{C}} 157.37$, 103.56, 164.57 and 98.96 confirmed the location of $\delta_{\mathrm{H}}$ 6.15 and 6.44 at H-8 and H-6 of the A-ring, respectively. Another set of HMBC correlations between $\delta_{\mathrm{H}}$ 6.90 with quaternary sp ${ }^{2}$ carbon at $\delta_{\mathrm{C}} 121.17$ and $\delta_{\mathrm{H}}$ 7.91 with quaternary sp ${ }^{2}$ carbon at $\delta_{C} 161.46$ confirmed the presence of $\mathrm{AA}^{\prime} \mathrm{XX}$ ' ring system in $\mathrm{B}$ ring. The olefinic proton at $\delta_{\mathrm{H}} 6.75$ gave ${ }^{3} \mathrm{~J} \mathrm{HMBC}$ correlation to $\delta_{\mathrm{C}} 103.56$ and 121.17 indicated that compound $\mathrm{A}$ is flavones group. The LC-MS spectra (Figure 2) showed a molecular ion $[\mathrm{M}+\mathrm{H}]^{+} 271.2195$ or $\left[\mathrm{M}^{+}\right] 270.2195$ indicates the molecular weight of the compound corresponds to the molecular weight of apigenin and also corresponds to molecular formula $\mathrm{C}_{15} \mathrm{H}_{10} \mathrm{O}_{5}$ [10].

Compound $\mathrm{A}$ was evaluated for its cytotoxicity against the P-388 murine leukemia cells with $\mathrm{IC}_{50} 14.13$ $\mu \mathrm{g} / \mathrm{mL}$. This result suggested that phenolic group on apigenin may be an important structural feature for $\mathrm{cy}$ totoxic activity.

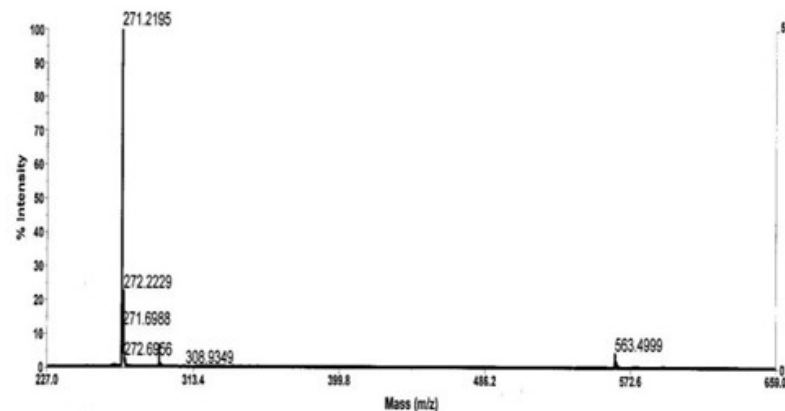

Figure 2. MS spectra of compound A

\section{CONCLUSIONS}

Isolation and purification of ethyl acetate fraction 12 (F-12) obtained from fractionated of methanolic extract of $M$. gigantifolia leaves done using column chromatography, centrifugal chromatography, and recrystallization using different system solvent has been done. Based on spectroscopic data concluded that compound $\mathrm{A}$ is apigenin, which have moderate cytotoxicity activity against Murine leukemia P-388 cell lines $\mathrm{IC}_{50} 14.13 \mu \mathrm{g} / \mathrm{mL}$.

\section{ACKNOWLEDGMENT}

Author would like to thank you to Prof. Dr. Muhammad Hanafi and Puspa Dewi N. Lotulung, M.Sc. for interesting discussion.

\section{REFERENCES}

1. Zakaria R, Rosely NFN, Mansor M, Zakaria MY (2008) The distribution of Macaranga genus (family Euphorbiaceae) in Penang Island, Peninsular Malaysia. Journal of Bioscience. 19(2): 91-99.

2. Lim TY, Lim YY, Yule CM (2014) Bioactivity of leaves of Macaranga species in tropical peta swamp and non-peta swamp environments. Journal of Tropical Forest Science. 26(1):134-141.

3. Gunawan-Puteri MDPT, Kawabata J (2010) Novel $\alpha$ glucosidase inhibitors from Macaranga tanarius leaves. Food Chemistry 2010;123:384-389.

4. Darmawan A, Kosela S, Kardono LBS, Syah YM (2012) Scopoletin, a coumarin derivatives compound isolated from Macaranga gigantifolia Merr. Journal of App. Pharm. Sci. 2(12):175-177.

5. Darmawan A, Wahyudi PS, Soleh K, Kardono LBS, Sofa F (2015) Macarangin, a geranylated flavonoid and anticancer active compound isolated from ethyl acetate fraction of Macaranga gigantifolia leaves. Indonesian J. Pharm. 26(1):52-56.

6. Magadula, J.J (2014) Phytochemistry and Pharmacology of the Genus Macaranga: a Review. J. of Med. Plant Res. 8(21): 489-503.

7. Alley MC, Scudiero DA, Monks A, Hursey ML, Czerwinski MJ, Fine DL, Abbot BJ, Mayo JG, Shoemaker RH, Boyd MR (1998) Feasibility of drugs screening with panels of tumor cell lines using a microculture tetrazolium assay. Cancer Res.48:589-601.

8. Harneti D, Tjokronegoro R, Safari A, Supratman U, XeMin L, Mukhtar MR, Mohamad K, Awang K, Hayashi,H (2012) Cytotoxic triterpenoids from the bark of Aglaia smithii (Meliaceae). Phytochemistry Letters. 5:496-499.

9. Sahidin, Hakim EH, Juliawaty LD, Syah MY, Din LB, Ghisalberti EL, Latif J, Said IM, Achmad SA (2005) Cytotoxic properties of oligostilbenoids from the bark of $\mathrm{Ho}$ pea dryobalanoides. Z. Naturforsch. 60 (9-10):723-727.

10. Nawal HM, Atta EM (2013) Cytotoxic and antioxidant activity of Marrubium vulgare and its flavonoid constituents. 2nd International Conference on Chemical, Environmental and Biological Sciences (ICCEBS'2013). Dubai UEA:40-42. 